\title{
ENTRE O DESMATAMENTO E A LEGISLAÇÃO: QUESTÕES A SEREM CONSIDERADAS SOBRE A SITUAÇÃO RECENTE DAS ÁREAS DE PRESERVAÇÃO PERMANENTE DE PARAGOMINAS-PA
}

BETWEEN DEFORESTATION AND LEGISLATION: QUESTIONS TO BE DISCUSSED ABOUT THE RECENT SITUATION OF THE PARAGOMINAS' PERMANENT PRESERVATION AREAS

Victor André Pinheiro Cantuário ${ }^{1}$

http://orcid.org/0000-0002-1706-1016 http://lattes.cnpq.br/5400803841633748

Flávio dos Santos Oliveira ${ }^{2}$

http://lattes.cnpq.br/9330275650499172

https://orcid.org/0000-0001-6980-5585

Recebido em: 6 de abril de 2020

Aprovado em: 8 de junho de 220

RESUMO: O objetivo deste trabalho é o de apresentar e discutir informações relevantes a respeito da situação recente e mais geral das Áreas de Preservação Permanente localizadas no território do município de Paragominas, Estado do Pará (PA). Isto posto, a fim de se encaminharem tais observações, efetuou-se consulta e seleção de textos e pesquisas já produzidos e publicados sobre o tema no país, portanto, fazendo-se uso de procedimento metodológico de pesquisa com fontes bibliográficas. Para se compreender qual a situação legal e recente dessas áreas, recorreu-se ao que propõem a legislação brasileira específica e estudos como os de Pinto et al. (2009), Nunes (2015), Pereira et al. (2016) a esse respeito. Com este trabalho, espera-se contribuir para as discussões cada vez mais frequentes em diversos campos de estudo sobre as Áreas de Preservação Permanente e de igual forma demonstrar que apesar das inciativas dos Poderes Constituídos e da sociedade civil de Paragominas de combaterem o desmatamento pelo qual por décadas o município sustentou condição negativa junto aos registros do Ministério do Meio Ambiente, a situação dessas áreas ainda demanda cuidado, fiscalização e atenção frequentes, além do crescente interesse da sociedade civil pelas causas envolvendo o meio ambiente e de projetos gerenciados por empresas privadas e associações de reflorestamento cuja intenção é viabilizar medidas para que seja possível a redução dos severos danos já impingidos ao Bioma Amazônia.

Palavras-chave: Áreas de Preservação Permanente; Paragominas (PA); Código Florestal Brasileiro.

${ }^{1}$ Doutorando em Estudos Literários (UNESP). Professor do Curso de Licenciatura em Pedagogia, Campus Santana (UNIFAP).E-mail: loquorlatinae@hotmail.com.

${ }^{2}$ Especialista em Auditoria e Perícia Ambiental pela Universidade Estácio de Sá. E-mail: flavio.santos.moreno@hotmail.com. 


\begin{abstract}
The objective of this work is to present and discuss relevant information concerning the recent and most general situation of the Permanent Preservation Areas, giving special attention to those existing in the territory of Paragominas, in the Para State, Brazil. Considering this, to lead such observations, it was searched and selected works produced in Portuguese about the subject, having as methodological procedure that defined as bibliographical. In trying to understand the legal and recent situation of these areas, it is necessary to see what the specific law - the Brazilian Forest Code - says about it and at the same time to consult studies as those of Pinto et al. (2009), Nunes (2015), Pereira et al. (2016). It is expected that this work could contribute to the more frequent discussions about the issue in many fields of study and equally demonstrate that despite the actions executed by the local government and civil society in combating the deforestation that gave a negative condition view to the city for decades, the actual situation of the Permanent Preservation Areas in Paragominas still requires care, constant inspection and attention by the Public sectors and awareness in respect of environmental matters by the civil society and projects managed by the private sector intending to make viable measures to reduce the severe damages already caused to the nature in Brazilian Amazon Biome.
\end{abstract}

Keywords: Permanent Preservation Areas; Paragominas, PA; Brazilian Forest Code.

\title{
INTRODUÇÃO
}

As Áreas de Preservação Permanente têm se mostrado importante objeto de estudo para quem esteja inserido em campos disciplinares relacionados a temáticas ambientais ou interdisciplinares como o da ecologia política, mas não somente a estes, visto o assunto conter aspectos que podem ser discutidos em trabalhos cujo viés de concentração sejam políticas públicas, pois é questão da qual a sociedade civil também tem buscado se informar.

Ao longo da história do Brasil, mais ainda a partir do período republicano, principalmente desde a década de 1930, notam-se as preocupações com o meio ambiente adquirirem outros contornos, gradualmente perdendo terreno a ideia prévia de inesgotabilidade dos recursos naturais para se adotar postura mais crítica e voltada à garantia de conservação de áreas de tamanha importância para a configuração geográfica do país e mais ainda importantes para a manutenção do clima e das condições de vida no planeta.

Assim, cada legislação florestal brasileira, desde a primeira publicada por meio do Decreto n. 23.793/34, durante o Governo Provisório de Getúlio Vargas (1930-1934), passando-se pela publicação de um código mais formalizado, Lei n. 4.771/1965, cujo teor técnico deixava claro a pressão que o Governo Federal sofria naquela altura por parte de movimentos ambientalistas nacionais que se espelharam nos iniciados na Europa e EUA, ao longo da década de 1960, a favor da conservação do meio ambiente, combatendo o desmatamento e a caça predatória, buscou afinar o tom e os direcionamentos do país a respeito das questões ambientais.

Em função disso, pode-se afirmar que as raízes do ambientalismo no Brasil, com direcionamento mais político, estão fixadas na década de 1970, o que significa ter sofrido alguma influência da Conferência de Estocolmo, ocorrida em 1972, a qual tecia ferozes críticas contra 
a racionalidade do progresso a qualquer custo causando impactos de grande escala no meio ambiente. ${ }^{3}$

Pretendendo dar corpo à discussão referente às Áreas de Preservação Permanente, em especial aquelas localizadas no território do município paraense de Paragominas, o presente trabalho, apoiado nas discussões desenvolvidas por Pinto et al. (2009), Nunes (2015), Pereira et al. (2016) a esse respeito, estrutura-se em três momentos, tratando, inicialmente, de trazer o histórico legal a respeito do que se entende por Área de Preservação Permanente e a evolução da legislação a respeito do tema, contemplando o que diz a Constituição Federal de 1988 e os Códigos Florestais, desde a Lei de Getúlio Vargas, datada do ano de 1934, em seguida o Código de 1965, finalizando as considerações com o Código aprovado em 2012.

O segundo momento se dedicará a apresentar a partir da Constituição de 1988 e do Código Florestal expresso na Lei n. 12.651 e sua alteração pela Lei n. 12.727, ambas de 2012, conceituação de Áreas de Preservação Permanente, não desconsiderando as legislações anteriores nem as demais categorias conceituais, como Reserva Legal, contidas no citado Código.

O terceiro momento tratará de apresentar o histórico do município de Paragominas bem como aspectos de sua passagem de um dos municípios brasileiros que mais desmataram áreas florestais - em razão de uma das principais atividades econômicas nele desenvolvida ser o extrativismo madeireiro - para município modelo em políticas e ações favoráveis à preservação do meio ambiente, reflorestamento e recuperação de áreas severamente degradadas.

Entre os resultados obtidos com a investigação do problema das Áreas de Preservação Permanente de Paragominas está a percepção de que apesar das inciativas dos Poder Constituídos e da sociedade civil local de desenvolverem ações de combate ao desmatamento pelo qual por décadas o município sustentou condição negativa junto aos registros do Ministério do Meio Ambiente e de não constar, desde 2010, na lista divulgada pelo órgão federal dos municípios brasileiros com maior índices de desmatamento, a situação daquelas áreas ainda demanda cuidado, fiscalização frequente e atenção do Poder Público para que seja possível a redução dos severos danos já impingidos ao Bioma Amazônia por meio de atividades econômicas ilegais como a de exploração madeireira.

\section{AS ÁREAS DE PRESERVAÇÃO PERMANENTE: À LUZ DA CONSTI- TUIÇÃO FEDERAL E DA LEGISLAÇÃO AMBIENTAL BRASILEIRAS}

As Áreas de Preservação Permanente têm sido objeto de constante debate e revisão no contexto ambiental contemporâneo. Uma das razões disso se deve à natureza de sua existência legal, ou seja, como elas são assinaladas e entendidas pela legislação específica, citem-se o Código Florestal promulgado pela Lei n. 4.771, de 15 de setembro de 1965, e revogado pela Lei n. 12.651, de 25 de maio de 2012, que instituiu o Novo Código Florestal brasileiro, sendo a seguir alterado pela Lei n. 12.727, de 17 de outubro do mesmo ano, e a Constituição Federal de 1988, cuja atenção e abertura às questões sociais e ambientais é consideravelmente maior que nas anteriores. ${ }^{4}$

3 Um perfil dos movimentos ambientalistas brasileiros, seu processo de formação e demandas são discutidos em: ALONSO, Angela; COSTA, Valeriano; MACIEL, Débora. Identidade e estratégia na formação do movimento ambientalista brasileiro. Novos Estudos, Cebrap, 79, p. 151-167, novembro 2007.

${ }^{4}$ Essa afirmativa procede da consulta aos textos das Constituições do período republicano $(1891,1934,1937,1946,1967)$, notando-se a ausência de menções aos bens físicos, ao meio ambiente e à sua preservação. A íntegra dos textos constitucionais pode ser consultada no sítio da Biblioteca Digital do Senado Federal, disponível em: 
A importância do assunto estaria justamente no fato de se fazer referência a preocupações recentes quanto à preservação e manutenção de áreas que gradualmente vêm - ao sabor da discussão e decisões políticas que ocorrem no país, por algumas vezes se imporem interesses político-econômicos acima de direitos e garantias contemplados tanto na Constituição quanto na legislação específica mencionadas - perdendo seu status e sua garantia de proteção, estando, em alguns casos, ameaçadas a desaparecerem dada a ampliação de áreas sujeitas ao desmatamento.

Outro ponto de debate e equívoco é o desconhecimento que advém da população ao decidir construir moradias nessas áreas, e de algumas autoridades públicas por não estarem cientes das modificações legais por que as mesmas vêm passando frequentemente.

No tocante à história do conceito de Áreas de Preservação Permanente, Ribeiro (2011, p. 3) resgata, antes de mais nada, o trajeto institucional que contribuiu para seu surgimento. Em suas palavras:

Na história do Brasil podemos identificar várias regulamentações de caráter ambiental considerando-se como marco a Lei 4.771 de 15 de setembro de 1965, que instituiu o novo Código Florestal Brasileiro. A partir da criação do Conselho Nacional do Meio Ambiente/CONAMA, instituído pela Lei 6.938 de 1981, que dispõe sobre a Política Nacional do Meio Ambiente, regulamentada pelo Decreto 99.274 de 1990, surgiu um órgão consultivo e deliberativo do Sistema Nacional do Meio Ambiente/SISNAMA. Após a Constituição Brasileira de 1988, com especificidades de caráter ambiental, há 22 anos, em 22 de fevereiro de 1989, foi promulgada a Lei no. 7.735, que criou o Instituto Brasileiro do Meio Ambiente e dos Recursos Naturais Renováveis IBAMA. A partir desses momentos, a gestão ambiental passou a ser integrada. Antes, havia várias áreas que cuidavam da questão ambiental em diferentes ministérios e com diferentes visões, muitas vezes contraditórias.

É possível compreender que, apesar do caminho legal iniciado com o Código de 1965, já no Governo Provisório de Getúlio Vargas, cujo período se estende de 1930 a 19345, há incidência do que seria então um primeiro Código Florestal brasileiro no Decreto n. 23.793, de 23 de janeiro de 1934 (revogado), ao passo que o Decreto n. 24.643, de 10 de julho de 1934, conhecido como Código de Águas, legislava sobre o usufruto racional das águas no Brasil, esclarecendo que até aquele momento o uso das águas era regulamentado por "legislação obsoleta, em desacordo com as necessidades e interesse da coletividade nacional" (BRASIL, 2003, p. 19).

Um dos problemas com o Decreto 23.793/34 é que não trazia em seu conteúdo qualquer referência às Áreas de Preservação Permanente e classificava as florestas no seu art. $3^{\circ}$ em: “a) protectoras; b) remanescentes; c) modelo; d) de rendimento", mas o uso de protetora aí diverge substancialmente da compreensão que se tem hoje, isto fica evidente atendo-se unicamente à ideia de conservação do "regimen das águas" (BRASIL, 2020).

O que fica claro por essas exposições é mais a preocupação com a modernização do país, marca do governo Vargas, do que com a proteção e guarda do meio ambiente, visto que este aspecto está presente de maneira imprecisa em seu Decreto e isso faz pensar no peso que recaiu sobre a lei de 1965, pois além da série de pressões acumuladas desde 1934, ainda se tinha um fator de maior impacto que era o surgimento das demandas por preservação do meio

$<$ http://www2.senado.leg.br/bdsf/handle/id/2/browse?type=title $>$.

5 Ver: FAUSTO, Boris. História do Brasil. - 12. ed. São Paulo: Editora da Universidade de São Paulo, 2006. p. $329-394$.

PRACS: Revista Eletrônica de Humanidades do Curso de Ciências Sociais da UNIFAP https://periodicos.unifap.br/index.php/pracs ISSN 1984-4352 Macapá, v. 13, n. 2, p. 373-398, jul./dez. 2020 
ambiente e a problematização da ideia de inesgotabilidade e dos severos danos causados ao meio físico pela exploração irresponsável de recursos, que serão objeto de crítica na Declaração resultante da Conferência de Estocolmo. ${ }^{6}$

Portanto, diante do contexto de seu aparecimento e das demandas em nível global por mais preservação é que se pontua: somente após a instituição do Código Florestal de 1965 poderse-á falar apropriadamente em Áreas de Preservação Permanente, pois o conceito é inserido nessa lei, ocorrendo desde aí até recentemente modificações significativas tanto no conceito quanto na existência efetiva dessas áreas.

O próximo capítulo na história das legislações florestal e ambiental brasileiras será definido no início da década de 1980, com a edição da Lei Federal n. 6.938, de 31 de agosto de 1981, durante o governo Figueiredo, o último da ditadura civil-militar, portanto, antes da vigente Carta de direitos.

O propósito dessa lei, amparada no art. $8^{\circ}$, item XVII, alíneas c, h, i, do texto constitucional de 1967, sobre as competências da União, era de instituir a Política Nacional do Meio Ambiente de maneira a regulamentar o uso dos recursos naturais (solo, água e ar), atentando para a conservação dos ecossistemas, recuperação de áreas que viessem a sofrer danos resultantes de uso indiscriminado e propor uma educação ambiental que pudesse contemplar todos sistema educacional. ${ }^{7}$

Além de outros marcos legais promulgados até o fim da década de 1980, estando a própria Constituição entre estes, o Governo Federal ainda sancionou a Lei n. 7.803, em 18 de julho de 1989, reformulando alguns artigos do Código de 1965, como o art. $2^{\circ}$ que trata de áreas de preservação permanente, mas como florestas e vegetação natural. Entre as modificações estão a maior delimitação dada às Áreas de Preservação Permanente, alterando o seu limite consideravelmente.

Os impactos da legislação formulada na década de 1960 serão sentidos tanto na Constituição de 1988, como já se mencionou, quanto a partir da década de 1990, momento em que no país ocorreram importantes discussões a respeito do meio ambiente, sendo a mais significativa dessas a Conferência Rio- $92^{8}$ cujo objetivo principal foi o de contribuir para a promoção da tomada de consciência por parte da população para os efeitos do desmatamento, da mudança climática, e os movimentos ambientalistas operaram papel fundamental nesse evento e em seus desdobramentos.

Com o aumento do desmatamento na década de 1990, mesmo após a Rio-92, o Governo Federal foi provocado a tomar medidas mais rígidas nesse quesito, o que resultou na Lei dos Crimes Ambientais (LCA) n. 6.905, de 12 de fevereiro de 1998, reforçando o Código de 1965, mas que precisou ser alterada pelo Decreto n. 6.514, de 22 de julho de 2008, para incluir

\footnotetext{
${ }^{6}$ Os princípios 3 e 5, por exemplo, tocam na necessidade de se manter "a capacidade da terra de produzir recursos renováveis" e que aqueles recursos "não renováveis da terra devem ser empregados de maneira que os guarde contra o perigo de sua futura exaustão e para garantir que os benefícios de tal emprego sejam compartilhados por toda humanidade." Ver: UNITED NATIONS. Report of the United Nations Conference on the Human Environment, Stockholm, 5-16 June 1972. p. 4. Disponível em: <http://www.un-documents.net/aconf48-14r1.pdf>. Acessado em: 15 jan. 2020.

7 O texto da Lei pode ser acessado no sítio da Presidência da República, disponível em: < http://www.planalto.gov.br/ ccivil_03/Leis/L6938.htm>.

8 Além da Declaração do Rio, disponível em: <https://www.un.org/en/development/desa/population/migration/generalassembly/docs/globalcompact/A_CONF.151_26_Vol.I_Declaration.pdf $>$, contendo os princípios a serem seguidos para se atingirem os objetivos definidos na Conferência a favor do meio ambiente, ainda se menciona a Agenda 21 Global, um conjunto de compromissos a serem cumpridos pelos 179 países signatários visando uma nova forma de desenvolvimento que possa ser considerada sustentável.
} 
sanções de natureza administrativa e penal com efeito imediato. ${ }^{9}$

Apesar dessas medidas, a situação de degradação do meio ambiente e do não respeito às categorias criadas no Código de 1965, Áreas de Preservação Permanente e Reservas Legais, persistiu, pois estas continuaram a ser alvo de invasões, desmatamentos e apropriações indevidas, sofrendo inclusive alterações quanto aos limites originalmente determinados por lei em legislações posteriores como a que instituiu o Código Florestal em vigor desde o ano de 2012; essas sucessivas alterações contribuíram para o maior risco de desmatamento das regiões em que essas áreas se encontram.

As preocupações não findam por aí e o debate se acirra em, pelo menos, três frentes: de um lado está a Bancada de deputados ruralistas ou Frente Parlamentar da Agropecuária no Congresso Nacional defendendo que as revisões feitas no Código Florestal estão impedindo a expansão do agronegócio porque estabelecem limites às propriedades e se não há expansão da produção, o déficit incidiria sobre a economia do país; de outro lado está a comunidade acadêmica defendendo que o novo Código deveria se pautar em princípios científicos, compreendendo a constituição geográfica do Brasil e privilegiando uma forma de desenvolvimento baseada em conceito agora integrado à legislação florestal, qual seja, sustentabilidade; partícipes da mesma querela são os ambientalistas justificando que o Código Florestal de 2012 deve ser integralmente vetado porque concorre para o aumento do desmatamento e outros danos que afetariam também a atividade agropecuária no país. ${ }^{10}$

Desses três grupos de atores institucionais, inegavelmente, aquele a dispor de maior poder de influência e força de modificação do cenário ambiental brasileiro, pelo papel desempenhado no Poder Legislativo, é o primeiro grupo e torna-se evidente também que grande parte de suas decisões estão motivadas por projetos que vão na contramão da linguagem de preservação do meio ambiente difundida por organismos e associações nacionais e internacionais.

Para Simionatto e Costa (2012), em estudo sobre a constituição do campo de força político reconhecido pela associação ao agronegócio e às empresas rurais no parlamento federal, as pautas a favor das quais os deputados da Bancada Ruralista se posicionam deixam claro os motivos pelos quais se opõem às revisões efetuadas no Código de 2012 e a parcialidade com que enxergam a questão, diante dos interesses que defendem.

O mesmo tom de parcialidade é proposto por Accioly e Sánchez (2012, p. 99) quando compreendem e problematizam a existência de todo um agrupamento antiecológico estabelecido no próprio Congresso Nacional, caracterizado pela sua visão contrária ao meio ambiente, considerando, os autores, que ruralista não é apenas o parlamentar proprietário e/ou sócio de imóvel rural ou vinculado ao agronegócio, mas todo aquele que "assume sem constrangimento a defesa de pleitos da bancada, não apenas em plenários e nas comissões, mas em entrevistas à imprensa e nas manifestações de plenário."

Ocorre que o último Código Florestal é resultado de mais de uma década de intensos debates, séries de pedidos de vista, apreciação e proposições até ser alterado, tomando o corpo textual final que lhe garantiu a aquisição do status e o peso de lei a ser observada e cumprida em todo o território nacional.

Tudo se iniciou no ano de 1999 com o Projeto de Lei n. 1.876, tendo sido o primeiro de

\footnotetext{
${ }^{9}$ O texto de ambas as leis pode ser consultado em: < http://www.fob.org.br/Pdfs/Resolucoes/LEI_9.605.pdf>.

10 BARBA, Mariana Della. Senado aprova texto-base do código florestal; entenda as mudanças. BBC Brasil, on-line, 6 de dezembro de 2011. Disponível em: <http://www.bbc.co.uk/portuguese/noticias/2011/12/111129_codigo_florestal_ plenario_mdb.shtml>. Acesso em: 15 jan. 2020
}

PRACS: Revista Eletrônica de Humanidades do Curso de Ciências Sociais da UNIFAP https://periodicos.unifap.br/index.php/pracs ISSN 1984-4352 Macapá, v. 13, n. 2, p. 373-398, jul./dez. 2020 
aproximadamente 36 projetos de lei a vingar naquilo para que fora proposto: substituir definitivamente o Código Florestal de 1965; contudo, de modo efetivo, o referido projeto de lei somente passou a

ser discutido mais intensamente a partir de julho de 2010, quando a Câmara começou a trabalhar no texto como uma referência para a criação de um novo Código Florestal. A proposta usa critérios diferentes daqueles utilizados no Código Florestal atual (lei 4.771/1965) para definir as áreas de proteção permanente (APPs) e Reserva Legal (RL), além de inserir o conceito de área rural consolidada, afetando o tamanho líquido total das áreas reservadas para este fim (MOREIRA DA SILVA et al., 2011, p. 3).

A sensação amargada por acadêmicos e ambientalistas ao final de todo esse capítulo, que durou mais de uma década, envolvendo a tramitação, os vetos e a promulgação pela presidente Dilma Rousseff, em maio de 2012, do novo Código Florestal pode ser resumida na compreensão da ex-senadora e ex-ministra do Meio Ambiente, fundadora do partido Rede Sustentabilidade, Marina Silva, ao concluir que os maiores vitoriosos com a aprovação do texto foram os deputados da Bancada Ruralista, pois, em sua leitura, menos que avanço, essa lei representa derrota frente ao que se tinha em termos de legislação ambiental até então (EM DISCUSSÃO, 2011).

Entre outras organizações, o Instituto Socioambiental ${ }^{11}$ (ISA) manifestou-se encaminhando documento diretamente à Presidência da República com solicitação de veto integral ao Código Florestal expondo razões suficientes para que a requisição fosse atendida; a resposta da presidência aos defensores de causas ambientais e à sociedade brasileira veio por meio da aprovação e sanção da Medida Provisória n. 571/2012, convertida na Lei n. 12.727, e do Decreto n. $7.830^{12}$ no mesmo dia, 17 de outubro de $2012 .{ }^{13}$

Com vários setores descontentes, as discussões sobre o veto do recente Código Florestal, apesar das modificações advindas da Lei 12.727/2012, parecem estar se acentuando e uma notícia que deixou a situação ainda mais delicada foi a série de benefícios concedidos pelo presidente Michel Temer à Bancada Ruralista no Congresso para angariar apoio na votação para arquivamento de ação que o denunciava por corrupção passiva, entre os quais refinanciamento de dívidas do agronegócio, contidos na Medida Provisória n. 793, de 31 de julho de 2017.14

${ }^{11}$ O ISA vinha acompanhando todos os processos que dizem respeito ao Código Florestal de 2012 como se pode consultar pelo acesso à sua página (https://www.socioambiental.org/pt-br).

12 O texto do Decreto pode ser consultado em: < http://www.planalto.gov.br/ccivil_03/_Ato2011-2014/2012/Decreto/D7830.htm>.

13 As polêmicas envolvendo o Código Florestal de 2012 persistiram após sua promulgação, atingindo o ano de 2017 com quatro Ações Diretas de Inconstitucionalidade (ADIs) apresentadas por ativistas do meio ambiente ao Supremo Tribunal Federal (https://oglobo.globo.com/sociedade/ciencia/meio-ambiente/novo-codigo-florestal-cinco-anos-depois-2143 2468), e um dos maiores questionamentos dessas ADIs fazia referência às Áreas de Preservação Permanente, às Reservas Legais e à possibilidade de regularização de áreas utilizadas irregularmente até julho de 2008, data do Decreto que alterou a Lei de Crimes Ambientais, algo visto como anistia aos responsáveis por ações de desmatamento. O posicionamento do STF sobre as quatro ações (4901, 4902, 4903, 4937) foi emitido em 28 fevereiro de 2018 (http://www.stf.jus.br/por$\mathrm{tal} / \mathrm{cms}$ /verNoticiaDetalhe.asp?idConteudo=370937), procedente em parte, reconhecendo a constitucionalidade ou in-

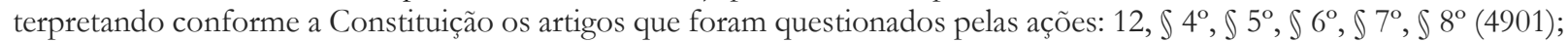

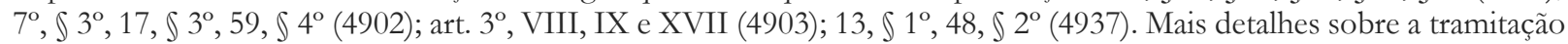
dessas ações podem ser acessados no Portal do STF (http://portal.stf.jus.br/processos/detalhe.asp?incidente= 4355097).

${ }^{14}$ MARTELLO, Alexandro. Governo abre mão de mais de $\mathrm{R} \$ 10$ bilhões com alívio de dívidas de ruralistas. G1 Globo, Economia, notícia 
Pelos indícios reunidos, a tensão envolvendo ambientalistas, acadêmicos, ruralistas e a sociedade civil, de um modo geral, torna-se mais forte com o passar do tempo e a obrigação de os órgãos governamentais, no Brasil, fornecerem e divulgarem em meios acessíveis informações sobre suas ações e decisões torna o processo de reivindicação de direitos e a imposição de ações contra legislações que venham a afetar direitos constitucionalmente adquiridos mais constante.

Nesse tom de reflexão a respeito da renovação do processo democrático rumo à maior participação da população na tomada de decisão, cabe retornar ao texto da lei a fim de se compreender como a legislação brasileira, Constituição Federal e legislações específicas para o meio ambiente como o Código Florestal, lidam com a definição do conceito de Áreas de Preservação Permanente.

A Constituição Federal de 1988, conforme indicou-se no início deste texto, possibilitou a abertura a temas que por décadas foram destituídos de discussão pública porque a percepção de quem legislava não estava em sintonia com as necessidades reais da população brasileira. $\mathrm{O}$ cenário muda de figura com a promulgação da referida lei porque, em comparação com as anteriores, pareceu, de fato, retratar melhor a condição do país.

Dentre tantas reivindicações feitas pela sociedade civil e por setores especializados estão as garantias voltadas ao meio ambiente e o local onde se pode encontrar tais garantias na CF é mais precisamente em um artigo, intitulado Do Meio Ambiente, cujo caput informa

Art. 225. Todos têm direito ao meio ambiente ecologicamente equilibrado, bem de uso comum do povo e essencial à sadia qualidade de vida, impondo-se ao Poder Público e à coletividade o dever de defendê-lo e preservá-lo para as presentes e futuras gerações. (BRASIL, 2019, p. 177)

Como se pode notar, a CF partilha a responsabilidade pela manutenção e defesa do meio ambiente entre o Poder Público e a sociedade civil e aqui se vê que de ambos os lados constatam-se falhas e omissões históricas no tocante à questão em tela, havendo, por parte da última, somente dos anos 1960 em diante ações em prol da defesa e conservação do meio ambiente e visando iniciativas de reflorestamento em áreas afetadas pelo desmatamento ou mesmo em áreas urbanas com a finalidade de se gerar equilíbrio no clima em locais que contam com pouca vegetação.

Por sua vez, observam-se deficiências nas ações do Poder Público cada vez que este se alheia total ou parcialmente daquilo que é sua missão constitucional nesse quesito e isso está relacionado a uma série de motivos envolvendo administrações municipais, estaduais e federais ao não pôr em prática o dito no $\$ 1^{\circ}$ do referido artigo e seus incisos, em que se pode ler:

$\int 1^{\circ}$ Para assegurar a efetividade desse direito, incumbe ao Poder Público:

I - preservar e restaurar os processos ecológicos essenciais e prover o manejo ecológico das espécies e ecossistemas;

II - preservar a diversidade e a integridade do patrimônio genético do País e fiscalizar as entidades dedicadas à pesquisa e manipulação de material genético;

III - definir, em todas as unidades da Federação, espaços territoriais e seus componentes a serem

on-line, 03/08/2017. Disponível em: <https://g1.globo.com/economia/noticia/governo-abre-mao-de-mais-de-r-10-bilhoes-com-alivio-de-dividas-de-ruralistas.ghtml>. Acesso em: 15 jan. 2020. Informe-se que a vigência desta MP alcançou seu termo em 28 de novembro de 2017 (http://www.planalto.gov.br/ccivil_03/_Ato2015-2018/2017/Congresso/adc066-mpv793.htm).

PRACS: Revista Eletrônica de Humanidades do Curso de Ciências Sociais da UNIFAP https://periodicos.unifap.br/index.php/pracs ISSN 1984-4352 Macapá, v. 13, n. 2, p. 373-398, jul./dez. 2020 
especialmente protegidos, sendo a alteração e a supressão permitidas somente através de lei, vedada qualquer utilização que comprometa a integridade dos atributos que justifiquem sua proteção;

IV - exigir, na forma da lei, para instalação de obra ou atividade potencialmente causadora de significativa degradação do meio ambiente, estudo prévio de impacto ambiental, a que se dará publicidade;

V - controlar a produção, a comercialização e o emprego de técnicas, métodos e substâncias que comportem risco para a vida, a qualidade de vida e o meio ambiente;

VI - promover a educação ambiental em todos os níveis de ensino e a conscientização pública para a preservação do meio ambiente;

VII - proteger a fauna e a flora, vedadas, na forma da lei, as práticas que coloquem em risco sua função ecológica, provoquem a extinção de espécies ou submetam os animais a crueldade. (BRASIL, 2019, p. 177)

A série de demandas legais emanadas do texto constitucional, pelo que se vê, sintonizamse historicamente com movimentos legais executados por outros países e instituições pretendendo dificultar que danos sejam causados ao meio ambiente e impondo a conscientização de todos os cidadãos por meio de educação formal a ser incorporada em atendimento ao inciso VI.

Possivelmente, a base textual para a elaboração do artigo 225 da CF de 1988 seja o artigo $2^{\circ}$ da Lei n. 6.938/1981, já mencionado, no qual, além das diversas tarefas a serem cumpridas para uma eficaz Política Nacional do Meio Ambiente, falava-se também em educação ambiental como um dos princípios para a efetivação dos objetivos relacionados à melhoria da qualidade das condições de vida e condição fundamental para o desenvolvimento socioeconômico nacional.

Voltando ao Código de Vargas, se se proceder a um breve exame que seja, nota-se que apesar de já expressar preocupação com questões vinculadas à preservação ambiental este não traz em sua redação conceitos tão definidos como o faz o Código de 1965, no qual aparece pela primeira vez a denominação oficial de "preservação permanente", ou seja, de Áreas de Preservação Permanente.

$\mathrm{Na}$ tentativa de se fazer comparação com a conceituação dessas áreas revogada em suas disposições pelo código de 2012, em vigor, tem-se, na lei de 1965, as medidas originalmente definidas para elas nos seguintes termos:

Art. $2^{\mathbf{o}}$ Consideram-se de preservação permanente, pelo só efeito desta Lei, as florestas e demais formas de vegetação natural situadas:

a) ao longo dos rios ou de outro qualquer curso d'água desde o seu nível mais alto em faixa marginal cuja largura mínima será:

1 - de 30 (trinta) metros para os cursos d'água de menos de 10 (dez) metros de largura;

2 - de 50 (cinqüenta) metros para os cursos d'água que tenham de 10 (dez) a 50 (cinqüenta) metros de largura;

3 - de 100 (cem) metros para os cursos d'água que tenham de 50 (cinqüenta) a 200 (duzentos) metros de largura;

4 - de 200 (duzentos) metros para os cursos d'água que tenham de 200 (duzentos) a 600 (seiscentos) metros de largura;

5 - de 500 (quinhentos) metros para os cursos d'água que tenham largura superior a 600 (seiscentos) metros; 
b) ao redor das lagoas, lagos ou reservatórios d'água naturais ou artificiais;

c) nas nascentes, ainda que intermitentes e nos chamados "olhos d'água", qualquer que seja a sua situação topográfica, num raio mínimo de 50 (cinquenta) metros de largura;

d) no topo de morros, montes, montanhas e serras;

e) nas encostas ou partes destas, com declividade superior a $45^{\circ}$, equivalente a $100 \%$ na linha de maior declive;

f) nas restingas, como fixadoras de dunas ou estabilizadoras de mangues;

g) nas bordas dos tabuleiros ou chapadas, a partir da linha de ruptura do relevo, em faixa nunca inferior a 100 (cem) metros em projeções horizontais;

h) em altitude superior a 1.800 (mil e oitocentos) metros, qualquer que seja a vegetação (BRASIL, 2004, p. 21-22). ${ }^{15}$

Observe-se que o código de 1965 procura dar continuidade ao de 1934, porém, mais reduzido em número de artigos - enquanto este totalizava 111 artigos, aquele, 50 - e com linguagem mais objetiva sobre o que pretende determinar, diferenciando-se do antecessor ao apresentar a inovação da categoria de Áreas de Preservação Permanente, além de realizar exclusões como em relação à categoria de florestas que o Código de Vargas previa. ${ }^{16}$

Outro ponto de divergência entre os códigos se refere ao que deveria ser objeto de preservação ou proteção. Enquanto o Código de Vargas falava da "conservação das funções básicas dos ecossistemas naturais e (...) não somente daquelas que pudessem oferecer lenha, uma das principais fontes de energia no passado" (RIBEIRO, 2012, p. 4), o de 1965 tinha como propósito a "proteção dos recursos hídricos, encostas muito declivosas, áreas topograficamente diferenciadas, ambientes costeiros, dentre outros”, portanto, não apenas se detendo na proteção das "árvores e florestas” (RIBEIRO, 2012, p. 7).

Investigando o histórico das Áreas de Preservação Permanente, nota-se que as alterações em seus limites e natureza conceitual tiveram início com a Lei Federal n. 7.511, de 7 de julho de 1986, que impedia o desmatamento de florestas nativas independente da reconstituição da vegetação original e aumentava os limites das Áreas de Preservação Permanente (estendendose de 5 a 30 metros nas margens dos rios); esta foi revogada pela Lei n. 7.803, de 18 de julho de 1989, que novamente alterou os limites e a extensão das Áreas de Preservação Permanente impondo o reflorestamento a ser feito obrigatoriamente com espécies nativas (EM DISCUSSÃO, 2011).

Por sua vez, Araújo (2002, p. 3) comenta haver uma compreensão bastante rígida a respeito do regime de proteção das Áreas de Preservação Permanente defendendo que se tratariam de áreas com status de intocáveis, "admitida excepcionalmente a supressão de vegetação apenas nos casos de utilidade pública ou de interesse social legalmente previstos".

A partir disso, Viana (2004, p. 61) assim expressa entendimento a respeito dessas áreas:

A área de Preservação permanente (APP) pode ser conceituada como áreas localizadas nas propriedades, públicas ou privadas, cujos limites são fixados pela lei ou por ato do Poder Público competente conforme as características geomorfológicas do terreno, visando a preservação dos

15 Com a alteração dessa lei pela 7.803/1989 (http://www.planalto.gov.br/ccivil_03/leis/L7803.htm), a redação do texto sofreu modificações e ao item a) foram acrescidos os pontos 4 e 5 . O texto original integral pode ser consultado no sítio da Câmara dos Deputados (https://www2.camara.leg.br/legin/fed/lei/1960-1969/lei-4771-15-setembro-1965-369026publicacaooriginal-1-pl.html).

16 Sobre essas distinções, ver: MILARÉ, Édis. Direito do meio ambiente: a gestão ambiental em foco: doutrina, jurisprudência, glossário. São Paulo: Editora Revista dos Tribunais, 2009. p. 740-748. 
atributos ambientais e dos recursos hídricos do ecossistema no qual estão integradas. A finalidade é de que tais áreas não devam ser objeto de exploração, mantendo-se intactas suas funções ecológicas.

Importante para fins de comparação com a descrição anterior, apresentar a definição contida no Código Florestal de 2012, que se encontra no Capítulo II, Das Áreas de Preservação Permanente, Seção I, intitulada Da Delimitação das Áreas de Preservação Permanente, com as devidas alterações indicadas entre parênteses:

Art. $4^{\circ}$ Considera-se Área de Preservação Permanente, em zonas rurais ou urbanas, para os efeitos desta lei:

I - as faixas marginais de qualquer curso d'água natural perene e intermitente, excluídos os efêmeros, desde a borda da calha do leito regular, em largura mínima de: (Incluído pela Lei no 12.727, de 2012).

a) 30 (trinta) metros, para os cursos d'água de menos de 10 (dez) metros de largura;

b) 50 (cinquenta) metros, para os cursos d'água que tenham de 10 (dez) a 50 (cinquenta) metros de largura;

c) 100 (cem) metros, para os cursos d'água que tenham de 50 (cinquenta) a 200 (duzentos) metros de largura;

d) 200 (duzentos) metros, para os cursos d'água que tenham de 200 (duzentos) a 600 (seiscentos) metros de largura;

e) 500 (quinhentos) metros, para os cursos d'água que tenham largura superior a 600 (seiscentos) metros;

II - as áreas no entorno dos lagos e lagoas naturais, em faixa com largura mínima de:

a) 100 (cem) metros, em zonas rurais, exceto para o corpo d'água com até 20 (vinte) hectares de superfície, cuja faixa marginal será de 50 (cinquenta) metros;

b) 30 (trinta) metros, em zonas urbanas;

III - as áreas no entorno dos reservatórios d'água artificiais, decorrentes de barramento ou represamento de cursos d'água naturais, na faixa definida na licença ambiental do empreendimento; (Incluído pela Lei no 12.727, de 2012).

IV - as áreas no entorno das nascentes e dos olhos d'água perenes, qualquer que seja sua situação topográfica, no raio mínimo de 50 (cinquenta) metros; (Redação dada pela Lei no 12.727, de 2012).

$\mathrm{V}$ - as encostas ou partes destas com declividade superior a $45^{\circ}$, equivalente a $100 \%$ (cem por cento) na linha de maior declive;

VI - as restingas, como fixadoras de dunas ou estabilizadoras de mangues;

VII - os manguezais, em toda a sua extensão;

VIII - as bordas dos tabuleiros ou chapadas, até a linha de ruptura do relevo, em faixa nunca inferior a 100 (cem) metros em projeções horizontais;

IX - no topo de morros, montes, montanhas e serras, com altura mínima de 100 (cem) metros e inclinação média maior que $25^{\circ}$, as áreas delimitadas a partir da curva de nível correspondente a 2/3 (dois terços) da altura mínima da elevação sempre em relação à base, sendo esta definida pelo plano horizontal determinado por planície ou espelho d’água adjacente ou, nos relevos ondulados, pela cota do ponto de sela mais próximo da elevação;

$\mathrm{X}$ - as áreas em altitude superior a 1.800 (mil e oitocentos) metros, qualquer que seja a vegetação; $\mathrm{XI}$ - em veredas, a faixa marginal, em projeção horizontal, com largura mínima de 50 (cinquenta) metros, a partir do espaço permanentemente brejoso e encharcado. (Redação dada pela Lei no 12.727, de 2012) (LEHFELD; CARVALHO; BALBIM, 2013, p. 67-68). 
A leitura desse artigo, entre outros, faz perceber a significativa modificação por que passou o conceito de Áreas de Preservação Permanente desde a proposição original, no Código de 1965, até as resoluções, portarias, decretos, medidas provisórias e o mais recente Código de 2012, crendo-se que, certamente, haverá de passar, futuramente, por outras modificações para se adequar à visão de meio ambiente do governo e dos legisladores do momento e às demandas da sociedade civil inspiradas ou não pelas ondas ambientais e movimentos defensores da preservação do meio ambiente e dos biomas em geral, considerando suas particularidades e necessidades de manutenção e os valores atribuídos pela sociedade em cada momento histórico para tal conceito.

A respeito da maneira como essas áreas são vistas no Brasil, EUA e Suécia, Mattos (2006), problematizando a situação daquelas localizadas em áreas do município de Viçosa (MG), compara o tratamento dado às Áreas de Preservação Permanente entre os países citados e chega à conclusão de que somente aqui se tem limitação do uso dos recursos naturais existentes nessas áreas. Nos países estudados pela autora são permitidos os usos dos referidos recursos para fins domésticos ou comerciais desde que mantendo características de uso sustentável.

Comparando-se legislações florestais do Brasil, Portugal - modelo em políticas florestais para a Comunidade Europeia -, Finlândia, Canadá e Austrália é possível concluir que há nos países europeus uma maior abertura para o uso de Áreas de Preservação Permanente mantendo-se regulações de controle no uso dessas áreas, mas por questões culturais o êxito na fiscalização e respeito à legislação é satisfatório. Ao passo que nos dois últimos países citados, dadas as suas configurações geográficas caracterizadas por "grande extensão territorial e florestal, um possuir histórico de colonização extrativista, por consequência traz[em] uma legislação florestal mais rigorosa" (COSTA, 2008, p. 50).

A diferença quanto às Áreas de Preservação Permanente não é verificada apenas ao se compararem legislações de países, essa diferença fica evidente também nas legislações florestais internas, por exemplo, a Fundação COPPETEC (Coordenação de Projetos, Pesquisas e Estudos Tecnológicos), órgão de direito privado que mantém vinculo em ações de ensino, pesquisa e extensão com a Universidade Federal do Rio de Janeiro (UFRJ), informa algumas das principais diferenças encontradas entre o Código Florestal e as legislações correlatas.

Esses desvios estariam relacionados às categorias conceituais utilizadas nas devidas legislações, à regulamentação, por vezes, incipiente e à própria escrita das leis que deixa margens para interpretações ou dúvidas e isso vem sendo paulatinamente corrigido nas legislações mais atuais. Esses problemas estavam muito presente nos dois primeiros códigos, de 1934 e $1965 .{ }^{17}$

Tais "discrepâncias na legislação florestal”, segundo Neiva (2009, p. 24), "além de evidenciar a fragilidade dela perante a sua aplicabilidade, também contribuem para que a mesma não seja devidamente respeitada, especialmente quanto à ocupação de margens de rios, uma prática historicamente comum nas sociedades humanas."

Em consonância com esse pensamento e mantendo o tom advogado por Araújo (2002) sobre o rígido regime de proteção dessas áreas, Borges et al. (2011, p. 1209) discutem que independe do lugar no qual legalmente se estabeleceu uma Área de Preservação Permanente e "se há ou não cobertura vegetal, se é em área urbana ou rural, deve ser considerado intocável,

17 Ver: FUNDAÇÃO COPPETEC. Plano de Proteção de Mananciais e Sustentabilidade no uso do solo. Agência Nacional de Águas (ANA), dezembro de 2002. Disponível em: < https://www.ana.gov.br/AcoesAdministrativas/ContratosConvenios/_docs/019_2001/pgrh-re-029-r0.pdf>. Acessado em: 17 jan. 2020.

PRACS: Revista Eletrônica de Humanidades do Curso de Ciências Sociais da UNIFAP https://periodicos.unifap.br/index.php/pracs ISSN 1984-4352 Macapá, v. 13, n. 2, p. 373-398, jul./dez. 2020 
com exceção dos casos de utilidade pública, interesse social e atividades de baixo impacto ambiental definidos pelo CONAMA".18

Cabe perceber que legalmente ou não as Áreas de Preservação Permanente enfrentam uma série de obstáculos para permanecerem conservadas. Ora o desconhecimento da legislação se impõe como aspecto definidor do uso indevido, ora as constantes modificações em seus limites legais, motivadas por interesses políticos ou movimentos ambientalistas, fazem retroceder ou avançar a compreensão destas áreas, some-se a isso a dificuldade de fiscalização e o desnivelamento verificado entre o Código Florestal brasileiro, portanto, lei federal e as resoluções estaduais e municipais voltadas às matérias ambientais e, finalmente, determinações particulares impostas por força de lei para fins de uso dessas áreas sem que sejam respeitadas as regulações a serem praticadas após o uso e manejo de seus territórios.

\section{PARAgominas: PRÁticas de desmatamento, Políticas de CONSERVAÇÃO AMBIENTAL E A SITUAÇÃO DAS ÁREAS DE PRESER- VAÇÃO PERMANENTE}

Localizado a $320 \mathrm{~km}$ de Belém, na mesorregião sudeste do Estado do Pará, norte do Brasil, Paragominas "possui uma área de 19.330 quilômetros quadrados (1,5\% da superfície do Pará) e uma população de 90.819 habitantes ${ }^{19}$ (1,3\% da população paraense)" (PINTO et al., 2009, p. 9).

No sítio oficial da cidade de Paragominas encontram-se informações breves sobre a fundação e a história do município paraense. De acordo com o portal, a data 23 de janeiro de 1961 é significativa para seus habitantes, pois marca o lançamento da pedra fundamental (PMP, 2020, on-line).

Outro aspecto a chamar atenção é o fato deste município não ter surgido como resultado da colonização iniciada no país no século XVI, nem pelas missões religiosas, consequência da presença portuguesa nestas terras ${ }^{20}$, mas ter sido fundado por iniciativa de Célio Resende de Miranda, a respeito de quem não se reportam maiores detalhes.

Ele, que sempre ouvira falar das imensas riquezas paraenses, de suas matas inexploradas, clima propício à agropecuária etc., fez sua primeira viagem ao Pará em 1958. Sobrevoando as áreas, vários pontos foram estudados até que sua vista encontrou o local perfeito, entre os rios Gurupi e Capim.

No mesmo ano, Célio Miranda foi ao encontro do presidente Juscelino Kubitschek, pedir autorização para iniciar no Pará o seu grande sonho, de erguer uma cidade em plena Amazônia. O presidente Juscelino Kubitschek mostrou grande interesse pelos planos do corajoso mineiro, concluindo que o projeto, além de evitar a invasão das terras por estrangeiros ou aventureiros, também poderia ajuda a povoar a região.

Apoiando os planos de Célio Miranda, o presidente deu-lhe um documento que deveria ser

\footnotetext{
18 Consulte-se a esse respeito a Resolução n. 429, de 28 de fevereiro de 2011 que dispõe sobre a maneira como se deve proceder à recuperação das Áreas de Preservação Permanente, disponível em: < http://www2.mma.gov.br/port/conama/>.

${ }^{19}$ De acordo com o último Censo do IBGE, de 2010 (https://cidades.ibge.gov.br/brasil/pa/paragominas/panorama), a população do município atingiu o número de 97.819 pessoas, estimando-se até 2019 uma população de 113.145 habitantes.

${ }^{20}$ Ver: MENDES, Claudinei Magno Magre. A questão da colonização no Brasil: historiografia e documentos. Imagens da Educação, v. 2, n. 2, p. 1-13, 2012.
} 
entregue ao governador do Pará, na época Jarbas Passarinho. Nesse documento, Juscelino solicitava ao governo paraense que fosse cedida a Célio Miranda a gleba de terra por ele escolhida. Além de receber a concessão da terra, Célio ainda foi presenteado com uma planta elaborada pelo urbanista Lúcio Costa, a qual havia concorrido, junto a outras, para o projeto de construção de Brasília, classificando-se em $4^{\circ}$ lugar. Este projeto foi obtido por Célio Miranda através da doação por intermédio do geólogo Jofre Mozart Parada, que na época trabalhava em Brasília. A planta fora planejada em formato tri-hexagonal e como não havia a quantidade necessária de recursos, a planta original sofreu algumas modificações (PMP, 2020, on-line).

Mencione-se que apesar de receber a denominação de fundador, deixando transparecer que estaria sozinho no empreendimento, Célio Rezende de Miranda contou com o apoio de Manoel Alves de Lima, Eliel Pereira de Faustino, Severino Guimarães, também considerados fundadores, para dar nome à nova cidade. Conta-se que o episódio se passou assim:

Num certo dia de inspiração, disse ele que estando em terras localizadas no Estado do Pará, sendo os pioneiros goianos e ele, o idealizador do projeto, nascido em Minas Gerais, mineiro bem como os investidores que haviam adquirido as Glebas de terras, gerando o capital necessário, o nome mais adequado seria Paragominas:

Pará: Estado onde seria fundada a cidade.

Go: (Goiás) em homenagem aos componentes da caravana que colonizou a cidade.

Minas: Estado de origem do idealizador da cidade, Célio Miranda, prestando uma homenagem aos requerentes das 200 Glebas de terras, investidores que em sua maioria eram mineiros.

A ideia teve a aceitação de todos. O entusiasmo foi tanto que logo arranjaram uma tábua de madeira, escreveram o nome da cidade com uma pedra de carvão e, abaixo do nome Paragominas, a frase "todos a favor" (PMP, 2020, on-line).

Dados coletados pelo IBGE (2020, on-line) e disponíveis para consulta acrescentam outros detalhes a respeito da constituição de Paragominas e informam, de seu histórico e elevação à categoria de município, o seguinte:

O território de Paragominas, uma das mais recentes unidades autônomas do Estado do Pará, localizado na zona fisiográfica de Guajarina, pertenceu, em tempos remotos, ao distrito-sede do município de São Domingos do Capim e ao distrito de Camiranga, em Vizeu. Os seus fundamentos históricos foram lançados em 1958, pelo desbravador Ariston Alves da Silva, quando após ter atravessado a bacia do Capim, ali estabeleceu-se com a primeira roça de arroz.

Desconhece-se precisamente, a data da criação do núcleo populacional que originou a atual cidade. Sabe-se, porém que fora formado por colonizadores goianos, mineiros, baianos e paulistas, logo depois dos trabalhos de demarcação e venda dos lotes de terra.

Com a implantação da rodovia BR-010, que liga Belém a Brasília, passando por Paragominas, o desenvolvimento da atividade pecuária naquela localidade foi agilizado, e, em pouco tempo, tornou-se a base econômica municipal.

Ainda no sítio do IBGE (2020, on-line), é citada legislação que contribuiu para as modificações no status de Paragominas, ascendendo à condição de município e distrito, Lei n. 3.225, de 04 de janeiro e 1965, desmembrando-se dos municípios paraenses de São Domingos do Capim e Viseu e conquistando autonomia territorial.

Apesar de atualmente ser conhecida como cidade planejada e verde, por algum tempo Paragominas alimentou outra denominação nada favorável: de uma das cidades brasileiras com

PRACS: Revista Eletrônica de Humanidades do Curso de Ciências Sociais da UNIFAP https://periodicos.unifap.br/index.php/pracs ISSN 1984-4352 Macapá, v. 13, n. 2, p. 373-398, jul./dez. 2020 
maior índice de desmatamento. "Lá, até a década passada, desmatava-se como em poucos outros lugares da Região Norte. Prova disso é que o município já abrigou o maior polo madeireiro ilegal do país", sendo que a ilegalidade presente em Paragominas, trouxe excesso de violência, "o que fez com que muitos se referissem à cidade como 'Paragobalas"” (HERZOG, 2011).

Em fins de 2007, a cidade ocupava a $33^{a}$ posição, segundo lista ${ }^{21}$ divulgada pelo Ministério do Meio Ambiente (PMP, 2020), de municípios brasileiros que mais desmatavam a floresta amazônica e após a operação "Arco de fogo" da Polícia Federal, em março de 2008, foi assinado o "Projeto Município Verde", firmado entre autoridades do poder público, governo municipal e entidades não-governamentais.

Ao completar um ano de existência do projeto citado acima, a queda nos índices de desmatamento no município atingiu a impressionante taxa de $90 \%$, contando-se com mais de $80 \%$ de propriedades rurais com registro no Cadastro Ambiental Rural (CAR), um marco histórico em termos de políticas ambientais para o Estado do Pará.

Por fim, em março de 2010, foi divulgada oficialmente uma notícia muito importante para a cidade: "Paragominas foi o primeiro município da Amazônia a ser retirado da lista crítica do MMA [composta por 36 municípios], segundo Portaria $N^{\circ}$ 6722, de 24 de março de 2010" (MARTINS et al., 2013, p. 1283).

A iniciativa de criar estratégias de preservação e proteção ao meio ambiente em Paragominas, ao que tudo indica, não se restringiu somente às florestas, outros setores também foram contemplados com ações ou projetos visando a reversão de preocupantes quadros de agressão ao meio físico, uma dessas ações, por exemplo, estendeu-se à pecuária:

Criado em 2011, em Paragominas, no Pará, o projeto Pecuária Verde está se transformando em modelo para a Amazônia.

O projeto combina pecuária moderna e preservação da Floresta Amazônica. Com orientação de cientistas renomados, ele consegue aumentar a produtividade de fazendas de gado e, ao mesmo tempo, proteger ou até recuperar áreas de floresta (IASI, 2014, negrito do autor).

Aliada aos aspectos mencionados a respeito do pioneirismo de Paragominas quanto à preocupação em desenvolver políticas florestais para garantir a preservação do meio ambiente e mais detidamente das Áreas de Preservação Permanente existentes no município, deve ser incluída a Lei n. 644/2007, de 23 de maio de 2007, que, segundo a descrição no documento, ocupou-se em instituir a Política Municipal do Meio Ambiente (PMMA) e contou com a categorização, válida para o município, do que são consideradas Áreas de Preservação Permanente, assim disposta:

ART. 28 - São consideradas áreas de preservação permanente [nos limites do município]:

I - as nascentes dos rios;

II - as que abriguem exemplares raros da fauna e da flora;

${ }^{21}$ Essa lista foi criada a partir do Decreto n. 6321, de 21 de dezembro de 2007. De acordo com o art. $2^{\circ}$ deste, “o Ministério do Meio Ambiente editará anualmente portaria com lista de Municípios situados no Bioma Amazônia, cuja identificação das áreas será realizada a partir da dinâmica histórica de desmatamento verificada pelo Instituto Nacional de Pesquisas Espaciais - INPE”. Essa lista, Disponível em: <http://www.planalto.gov.br/ccivil_03/_Ato2007-2010/ 2007/Decreto/D6321.htm>.

22 O texto da referida Portaria está disponível em: < https://www.mma.gov.br/estruturas/sedr/_arquivos/portarias_ mma_66_67_e_68_de_24_de_maro_de_2010_138.pdf $>$. 
III - as que sirvam de local de pouso ou reprodução de espécies migratórias;

IV - as que apresentem indícios ou vestígios de sítios arqueológicos;

$\mathrm{V}$ - a cobertura vegetal que contribua para a resistência das encostas ou parte destas, com declividade superior a quarenta e cinco graus, equivalente a cem por cento na linha de maior declive;

VI - as florestas e demais formas de vegetação, de acordo com o previsto na Lei Federal $\mathrm{n}^{\mathrm{o}}$ 4.771, de 15 de setembro de 1965 , artigo $\underline{2}^{\circ}$, alínea a, itens $1,2,3$, 4, e 5 , na redação da Lei Federal no 7.803 , de 18 de julho de 1989, no que couber dentro da realidade do Município de Paragominas.

Parágrafo Único - Nas áreas de preservação permanente não serão permitidas atividades que, de qualquer forma, contribuam para descaracterizar ou prejudicar seus atributos e funções essenciais (PMP, 2007, p. 11).

Portanto, valendo-se do que já existia no Código Florestal de 1965 e das regulamentações publicadas da década de 1980 a 2007, a Prefeitura de Paragominas deu um salto qualitativo no sentido de fazer valer, no contexto de preparação para o surgimento do Projeto Município Verde, quase um ano depois da Lei de 2007, legislação sobre a política ambiental do município e demonstrando preocupação, em nível institucional, com a maneira de agir em se tratando de Áreas de Preservação Permanente.

É importante mencionar que, segundo informações disponibilizadas e atualizadas pelo Ministério do Meio Ambiente, até 13 de setembro de 201723, o município de Paragominas permanecia fora da lista dos municípios prioritários para ações de prevenção, monitoramento e controle do desmatamento no Bioma Amazônia, nesse ano composta de 39 municípios e não mais de 36 como em 2007, quando saiu decreto determinando a divulgação desses dados. Porém, Paragominas compõe a lista de 21 municípios com desmatamento monitorado e sob controle.

A fim de se compreender, de maneira geral, a situação das Áreas de Preservação Permanente no município de Paragominas, neste momento três considerações fundamentais serão postas para direcionarem a discussão dos resultados obtidos com o levantamento bibliográfico realizado. A primeira se relaciona aos objetivos e benefícios dispostos pela conservação e manutenção dessas áreas. A segunda sobre o estado real em que elas se encontram. A terceira sobre o que fazer a partir das respostas obtidas na segunda consideração.

Sobre a primeira consideração, segundo a Sociedade Brasileira para o Progresso da Ciência (SBPC, 2011), antes se deve mencionar que quaisquer resultados positivos advindos da conservação das Áreas de Preservação Permanente, não somente no caso de Paragominas, mas em nível nacional, estão intimamente relacionados com os serviços ecossistêmicos, os quais envolvem quaisquer benefícios que de maneira direta ou mesmo indiretamente resultem do contato humano com ecossistemas.

Alguns desses benefícios se configuram, por exemplo, nos alimentos retirados do meio físico, no solo utilizado para, entre outras coisas, plantio e na regularização das condições ambientais a fim de se tornarem favoráveis às ações de sobrevivência para todas as espécies que coexistem nesse meio. ${ }^{24}$

23 A de 2017, até o presente momento, foi a última lista divulgada. Essas informações podem ser consultadas em: $<$ http://combateaodesmatamento.mma.gov.br/images/conteudo/lista_municipios_prioritarios_AML_2017.pdf > .

24 Outros detalhes desse conceito podem ser obtidos em: ANDRADE, Daniel Caixeta; ROMEIRO, Ademar Ribeiro. Serviços ecossistêmicos e sua importância para o sistema econômico e o bem-estar humano. Texto para 
Adentrando nessa consideração, explicação ao alcance pode ser aventada a partir de estudos dedicados ao tema como se pode perceber por dados disponíveis em Nunes (2015) a respeito da necessidade urgente de conservação e manutenção das Áreas de Preservação Permanente estar não apenas no cumprimento da lei, mas nos benefícios que por si só elas oferecem ao meio ambiente e à população que direta ou indiretamente vive em seus entornos, pois

Entende-se, sim, que tais áreas a serem protegidas fazem parte de uma estratégia produtiva que potencializa a conservação da água, do solo e da agrobiodiversidade em qualquer imóvel rural. Tal afirmação fundamenta-se no fato de que, em terras sob cobertura florestal, o sistema radicular, serrapilheira e vegetação adensada das matas conseguem, juntos, reter em média $70 \%$ do volume das precipitações, regularizando a vazão dos rios, contribuindo para a melhoria na qualidade da água (SBPC, 2011, p. 38).

Ademais, condições ambientais adequadas tanto para a polinização biótica quanto abiótica 25 dependem da preservação dessas áreas de maneira a que se mantenha o fluxo, no caso da polinização biótica, de espécies de insetos e animais responsáveis por esta prática. E como último contributo a ser mencionado, as Áreas de Preservação Permanente, citem-se as de Paragominas, auxiliam "para diminuir o isolamento dos poucos fragmentos maiores [de vegetação], funcionando como trampolins ecológicos no deslocamento das espécies pela paisagem”. E nos casos em que essas áreas estão severamente danificadas ou são inexistentes, "os fluxos biológicos seriam muito prejudicados, acelerando ainda mais o processo de extinção" (SBPC, 2011, p. 47).

No tocante à segunda consideração, o estudo de Martins et al. (2013), realizando mapeamento em alta resolução ${ }^{26} \mathrm{com}$ auxílio de monitoramento adequado e programas desenvolvidos para essa finalidade, traz dados importantes para o entendimento real da situação das Áreas de Preservação Permanente de Paragominas, relatando-se não um aspecto específico destas, mas tencionando-se compreender a totalidade do problema por que estão passando visto que todos os elementos envolvidos - constituição hídrica, composição de solo e formação do bioma existente - interferem diretamente na percepção que delas se tem, instruindo-

\footnotetext{
Discussão. IE/UNICAMP, n. 155, p. 1-44, fev. 2009. Disponível em: <http://www.avesmarinhas.com.br/Servi $\%$ C3\%A7 $\quad$ os $\% 20$ ecossist $\%$ C3 $\%$ AAmicos $\% 20 \mathrm{e} \% 20$ sua $\% 20 \mathrm{im}-$ port $\%$ C $3 \%$ A 2 ncia $\% 20$ econ $\% \mathrm{C} 3 \%$ B 4 mica.pdf $>$.

${ }^{25}$ Estudos sobre a diferença e importância dos polinizadores bióticos (abelhas, moscas etc.) e abióticos (água e vento) podem ser consultados em: CENTRO DE GESTÃO E ESTUDOS ESTRATÉGICOS. Importância dos polinizadores na produção de alimentos e na segurança alimentar global. - Brasília, DF, 2017. Disponível em: <https://www.cgee.org.br/documents/10182/734063/polinizadores-web.pdf>.

26 As imagens incluídas nesse trabalho resultam de consulta a pesquisas nas quais estas são analisadas e a sua coleta se deu através da utilização de sistemas como o Sensor RapidEye e Landsat, os softwares Topcom Hiper, UTM (Universal Transverse Mercartor) e ENVI (Environment for Visualizing Images). Explique-se que “o RapidEye é um sistema composto por cinco satélites de sensoriamento remoto idênticos e em mesma órbita. A faixa da abrangência de coleta de imagens é de $77 \mathrm{~km}$ de largura e 1500 km de extensão”. Ver: ANTUNES, Mauro Antonio Homem; SIQUEIRA, Jessica Caroline dos Santos. Características das imagens RapidEye para mapeamento e monitoramento agrícola e ambiental. Anais XVI Simpósio Brasileiro de Sensoriamento Remoto - SBSR, Foz do Iguaçu, PR, Brasil, 13 a 18 de abril de 2013, INPE, p. 0548. Disponível em: <http://marte2.sid.inpe.br/col/dpi.inpe.br/marte2/2013/05.29.00.37.07/doc/p1253.pdf>. Acessado em: 20 jan. 2020. Ao seu turno, o Landset é uma série de satélites lançados pela NASA desde a década de 1960, "dedicado exclusivamente à observação dos recursos naturais terrestres. Essa missão foi denominada Earth Resources Technology Satellite (ERTS) e em 1975 passou a se chamar Landsat”. Ver: EMBRAPA MONITORAMENTO POR SATÉLITE. Satélites de Monitoramento. Campinas: Embrapa Monitoramento por Satélite, 2013. Disponível em: <https://www.cnpm.embrapa. br/projetos/sat/>. Acesso em: 02 fev. 2020.
} 
se maneiras mais eficazes de ação de modo a contribuir para sua preservação e manutenção.

A preocupação com a preservação, manutenção e recomposição de áreas desmatadas, como se viu, tornou-se uma constante em Paragominas, cidade pioneira e modelo em iniciativas e projetos de conservação ambiental tanto para o governo, por meio da efetivação de políticas públicas direcionadas ao meio ambiente, quanto para os habitantes, por meio de atitudes mais incisivas de fiscalização, de proposição de projetos sociais e ações de manutenção do quadro positivo já existente.

A partir do mapeamento do solo do município, considerando as particularidades de sua constituição e sua delimitação territorial, além de aspectos correlatos, Martins et al. (2013, p. 1288) detectaram que:

a cobertura do solo de Paragominas aponta que as florestas degradadas antigas, as quais apresentam sinais de exploração madeireira antiga, ocupam a maior parte de seu território: 60,48\%, com cerca de 11.700 quilômetros quadrados de extensão. Não identificamos a classe "floresta" no município, pois, após análise da série história de imagens Landsat, verificamos que a cobertura florestal sofreu algum nível de degradação no passado.

A segunda maior classe foi o desmatamento, com mais de 6 mil quilômetros quadrados, representando 32\% do município. As florestas degradadas vêm em seguida com mais de 500 quilômetros quadrados $(2,9 \%)$.

Os comentários de Martins et al. (2013) são corroborados por Nunes (2015, p. 67) quando a autora menciona que dos anos de 2002 a 2011, "Paragominas perdeu $1.261,1 \mathrm{~km}^{2}$ de floresta nativa, com um pico de desmatamento de 333,5 quilômetros quadrados em 2005 e 121,3km2 em 2009", isto é, no período descrito, Paragominas já vinha se mobilizando para combater práticas indiscriminadas de desmatamento ou ocupação indevida em Áreas de Preservação Permanente protegidas por lei, contudo, essas práticas, à revelia da lei ou por fiscalização deficiente, continuaram a ocorrer em todo o município, incluindo-se nos causadores de danos a essas áreas a ocupação irregular, uso indevido para atividades agrícolas descontroladas, construções ou edificações e criação de gado, como observável pelo estado do solo e da vegetação na Imagem 2.

Os dados descritos, apresentando as categorias mais persistentes de desmatamento, os percentuais discriminados e a extensão correspondente nos trechos anteriores podem ser verificados na Imagem 1 cuja legenda diferencia as classes mais recorrentes no mapa da cobertura do solo do município de Paragominas, desde as áreas de floresta degradada que mais sofreram com o desmatamento configurado na atividade de extração madeireira ilegal até as áreas edificadas através de núcleos populacionais já bem constituídos

Silva et al. (2011, p. 6663-6664) demonstram por comparação entre 1991 e 2008 uma situação preocupante e merecedora de atenção porque nesse período de tempo

foi possível verificar que algumas classes de cobertura da terra em 1991 sofreram o processo de desmatamento ao longo dos anos e foram destinadas a algum tipo de uso em 2008. Em 1991, a área total de desmatamento acumulado era de aproximadamente 446.0079 ha. No ano de 2008, já alcançava 626.448 ha, desconsiderando a ampla cobertura das nuvens.

Além do mais, pela configuração das classes, como observado na Imagem 1, colhida para se verificar a extensão do desmatamento, da presença humana e dos usos da terra no espaço

PRACS: Revista Eletrônica de Humanidades do Curso de Ciências Sociais da UNIFAP https://periodicos.unifap.br/index.php/pracs ISSN 1984-4352 Macapá, v. 13, n. 2, p. 373-398, jul./dez. 2020 
de tempo acima descrito, notou-se que “46,5\% das APPs são compostas por floresta degradada antiga, 39,8\% encontram-se desmatadas; e 8,7\% apresentam matas ciliares" 27 (MARTINS et al., 2013, p. 1288), compondo um preocupante cenário que a despeito das ações em reverso, ainda contém graves perigos para a conservação dessas áreas.

Imagem 1 - Mapa das APP de Paragominas (PA).

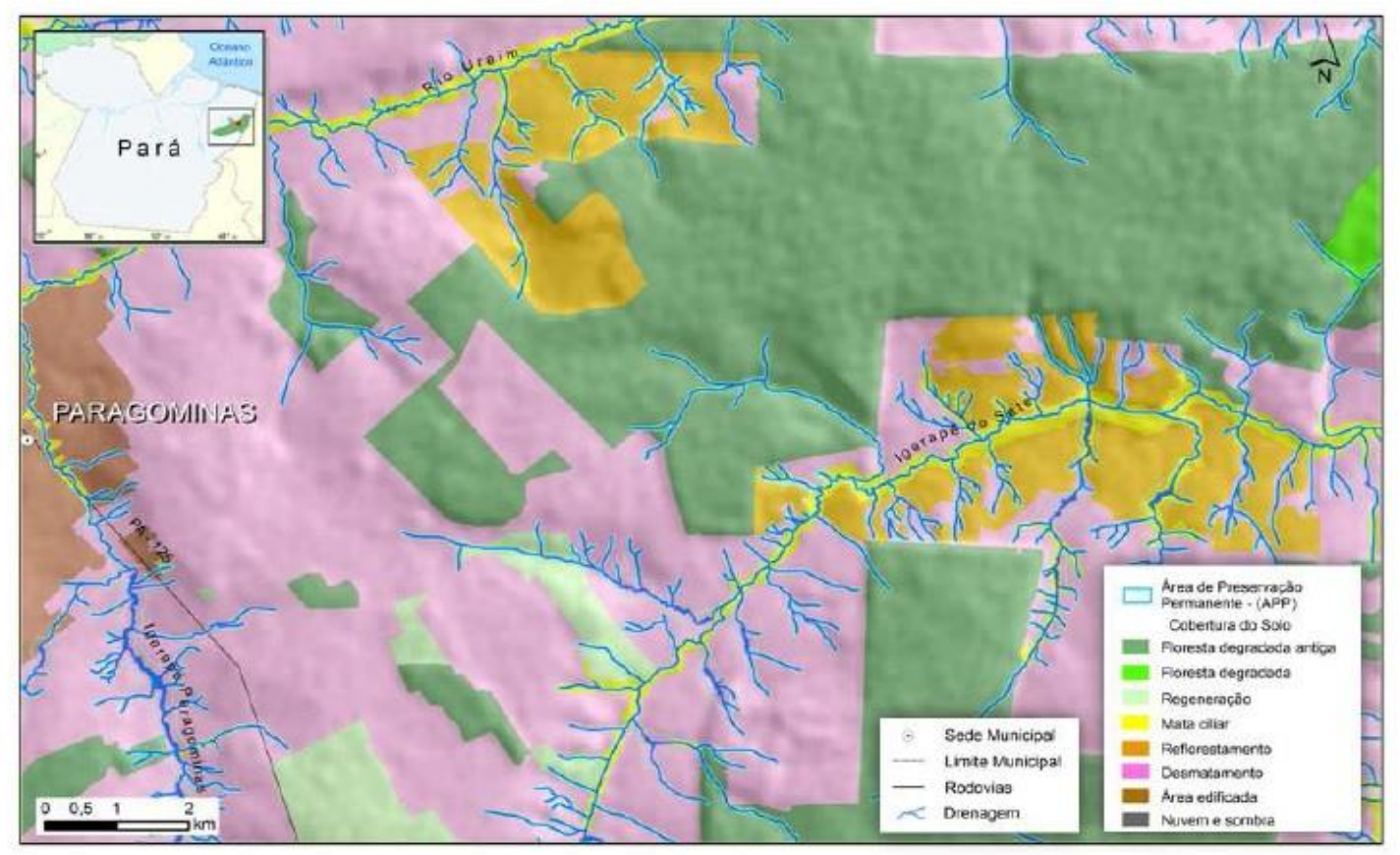

Fonte: MARTINS et al. (2013, p. 1289).

Desse modo, os danos causados por ações antrópicas em Áreas de Preservação Permanente como as do município de Paragominas incluem, entre outros: o avanço da ocupação humana, contribuindo para a gradual erosão do solo, o que há de interferir significativamente em sua composição, afetando a fauna e flora de seus entornos, provocando efeitos como de contaminação das águas e assoreamento dos corpos hídricos. Esses cenários apontam para uma situação que se repete e pode ser observada em diversos municípios ao longo do território nacional: a do descumprimento da legislação pertinente a essas áreas. ${ }^{28}$

Assim, na Imagem 1 é perceptível e delicado o avanço do desmatamento, representado na

27 Válido destacar uma definição do que sejam as matas ciliares, fundamentais tanto para a existência ou extinção das Áreas de Preservação Permanente quanto para sua conservação natural, assim, esclarece-se que podem ser entendidas como "vegetação remanescente nas margens dos cursos de água em uma região originalmente ocupada por mata e, como mata de galeria aquela vegetação mesofílica que margeia os cursos de água onde a vegetação natural original não era mata contínua”. Ver: KLEIN, Vilson Antônio; CHAVES, Adilar. Importância da mata ciliar (legislação) na proteção dos cursos hídricos, alternativas para sua viabilização em pequenas propriedades rurais. Passo Fundo, novembro de 2009. p. 4. Disponível em: <http://www.sertao.ifrs.edu.br/site/midias/arquivos/20091114104033296revisao_m... pdf $>$. Acessado em: 02 fev. 2020.

28 Diversos estudos apontam a ocorrência desses eventos em outras localidades. Alguns que podem ser mencionados são os de: ZANATA, Juliana Marina et al. Análise do uso do solo nas áreas de preservação permanente da microbacia Ribeirão Bonito, apoiada em técnicas de geoprocessamento. Revista Geonorte, Edição Especial, v. 2, n. 4, p. 1262-1272, 2012. E MENZORI, Ivan Damasco; FALCOSKI, Luiz Antonio Nigro. Mapeamento e análise das áreas de preservação permanente e dos corredores de integração ecológica de Araraquara, SP. Revista Ambiente Construído, Porto Alegre, v. 17, n. 2, p. 7-20, abr./jun. 2017. 
legenda pelos espaços em rosa; a extensão da floresta degrada, antiga e recente; a diminuição das matas ciliares, localizadas em espaços mínimos e a presença de áreas edificadas que provavelmente serão utilizadas para fins de construção civil ou habitação sem preocupação evidente com o meio ambiente.

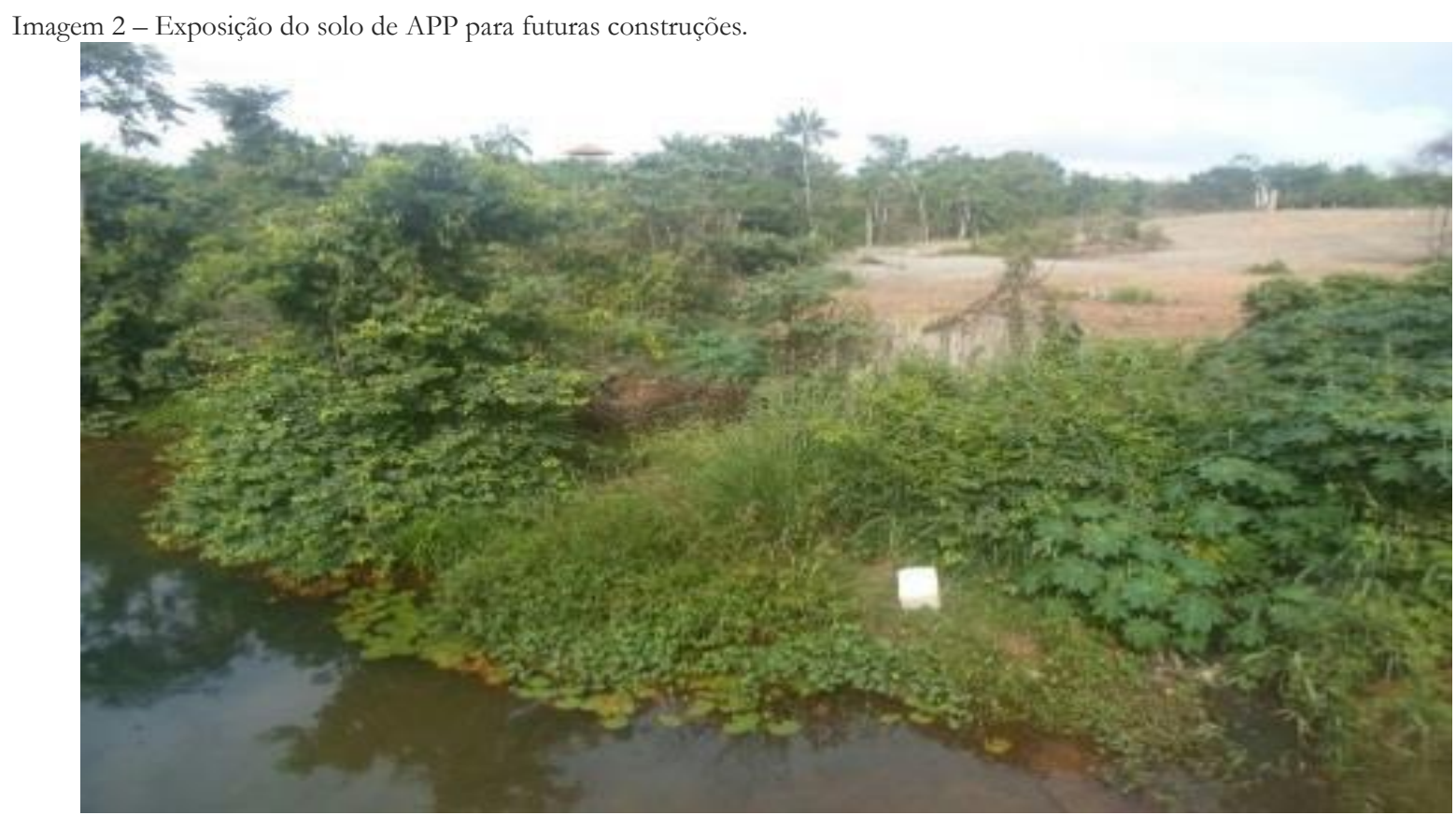

Fonte: PEREIRA et al. (2016, p. 1010).

E a presença humana nessas áreas causa a remoção, entre outros danos, de natureza permanente da vegetação nativa e, consequentemente, a exposição do solo (Imagem 2), estando motivada pelo uso da terra para produção agrícola ou construção civil de maneira desordenada a fim de se construir um cenário cada vez mais fortuito para a degradação do ambiente físico.

Mas não apenas isso, outras razões para a degradação dessas áreas que podem ser apontadas são a "utilização das APPs amazônicas para agricultura no período do verão amazônico e o não isolamento do gado, haja vista que Paragominas, por um grande período de sua história, teve a pecuária como principal base econômica." (NUNES, 2015, p. 135)

Além desses problemas relatados, outros relacionados à situação delicada das Áreas de Preservação Permanente dizem respeito a um dado preocupante relacionado ao Cadastro Ambiental Rural (CAR) e aos seus números tanto no Estado do Pará quanto no município de Paragominas.

Antes de dar continuidade a esse ponto, definição do que seja o referido cadastro se faz essencial para que se compreendam sua natureza e finalidades. A definição a seguir está disponibilizada no sítio do Ministério Meio Ambiente (2020, on-line), e de acordo com esse órgão federal

o Cadastro Ambiental Rural (CAR) é um instrumento fundamental para auxiliar no processo de regularização ambiental de propriedades e posses rurais. Consiste no levantamento de informações georreferenciadas do imóvel, com delimitação das Áreas de Proteção Permanente (APP), Reserva Legal (RL), remanescentes de vegetação nativa, área rural consolidada, áreas de interesse social e de utilidade pública, com o objetivo de traçar um mapa digital a partir do qual são 
calculados os valores das áreas para diagnóstico ambiental.

Ferramenta importante para auxiliar no planejamento do imóvel rural e na recuperação de áreas degradadas, o CAR fomenta a formação de corredores ecológicos e a conservação dos demais recursos naturais, contribuindo para a melhoria da qualidade ambiental, sendo atualmente utilizado pelos governos estaduais e federal.

Essa definição do Ministério do Meio Ambiente segue de perto as determinações a respeito do conceito contidas no art. 29 do Código Florestal de 2012, o qual, segundo o texto da lei, deve estar vinculado ao Sistema Nacional de Informação sobre o Meio Ambiente (SINIMA), constituindo-se em "registro público eletrônico de âmbito nacional, obrigatório para todos os imóveis rurais, com a finalidade de integrar as informações ambientais das propriedades e posses rurais" (LEHFELD; CARVALHO; BALBIM, 2013, p. 181), e está amparado no Decreto n. 7.830/2012 29 , promulgado no mesmo dia do Novo Código, cujo conteúdo é dedicado a dar esclarecimentos a respeito do Sistema de Cadastro Ambiental Rural (SICAR), do CAR e dos Programas de Regularização Ambiental (PRA). ${ }^{30}$

Contemplando a definição de CAR, Paragominas deveria estar, inclusive pelo retrocesso no desmatamento, em uma situação bastante confortável e, certamente, nenhum pouco digna de atenção, pois em 2011, 95\% das propriedades do município paraense estariam com cadastro regular no $\mathrm{CAR}^{31}$; contudo, pela natureza autodeclaratória deste tipo de cadastro, de acordo com os dados de 150 mil registros contidos no CAR do Pará, analisados pela Pública (Agência de Jornalismo Investigativo)

ao menos 108 mil apresentam alguma sobreposição com outros imóveis rurais; no total, a reportagem identificou quase 240 mil áreas de sobreposição, que somam mais de 14 milhões de hectares. A pesquisa revela também que em 48 mil cadastros as sobreposições preenchem mais de 100\% do imóvel rural, o que significa que diversos registros incidem sobre o mesmo imóvel. Além desses milhares de cadastros, ao menos 1.540 registros incidem diretamente sobre terras indígenas e outros 291 sobre Unidades de Conservação de Proteção Integral, áreas protegidas pertencentes à União. De acordo com as informações disponibilizadas, todos os cadastros estão ativos, embora 80\% deles constem como "Aguardando análise".

Mais grave, o levantamento encontrou 20 cadastros analisados e aprovados pela Secretaria Estadual de Meio Ambiente e Sustentabilidade (Semas) do Pará com incidência sobre terras indígenas, o que é proibido. (BARROS; BARCELOS, 2016)

O SICAR/PA 32 tem buscado corrigir essas deficiências registrando em seu sítio, até a data de 08 de maio de 2020, 224.594 cadastros realizados no Estado. Os números parecem ser

\footnotetext{
${ }^{29}$ Ver nota 10.

30 Outras regulamentações a respeito dessas três categorias legais vieram através do Decreto n. 8.235 , de 5 de maio de 2014, da Instrução Normativa n. 2/MMA, de 6 de maio de 2014 e da Instrução Normativa n. 3, de 18 de dezembro de 2014. O texto do primeiro ocupou-se de normas complementares para o PRA, instituindo o Programa Mais Ambiente Brasil, disponível em: < http://car.semas.pa.gov.br/leis/DECRETO8235.pdf >. A segunda tratou de aspectos relacionados ao SICAR e definiu procedimentos gerais para o CAR, disponível em: <http://car.semas.pa.gov.br/leis/ IN_CAR.pdf $>$. A terceira deu conta de instituir a Política de Integração e Segurança de Informação do Sistema do CAR, disponível em: <http://car.semas.pa.gov.br/leis/IN_CAR_3.pdf>.

31 Ver: BEEFPOINT. Entenda como Paragominas, no Pará, saiu da lista de maiores desmatadores e virou exemplo de pecuária sustentável. Notícia on-line, 24/11/2011. Disponível em: <https://www.beefpoint.com.br/entenda-como-paragominas-no-para-saiu-da-lista-de-maiores-desmatadores-e-virou-exemplo-de-pecuaria-sustentavel-76335/>. Acessado em: 10 mar. 2018.

32 Disponível em: <http://car.semas.pa.gov.br/\#/>.
} 
atualizados diariamente e outros dados podem ser obtidos através de consulta à página permitindo que estes possam ser contestados ou confirmados pelos próprios proprietários de imóveis rurais cujo CAR tenha sido devidamente realizado ou por público interessado em cotejar informações para finalidades distintas como pesquisa acadêmica.

A partir disto, um balanço que se tece diante dos dados expostos e das imagens utilizadas para vislumbre da situação ambiental de Paragominas em sua totalidade, partindo para a terceira e última consideração desta discussão, é a percepção de que mesmo após o início do "Projeto Município Verde" e a retirada do município da lista do MMA (PMP, 2020) de principais causadores de danos a áreas de floresta, entre as quais as Áreas de Preservação Permanente, ainda persiste a prática de se fazer uso impróprio, desordenado e descontrolado destas áreas para atividades que venham a comprometer sua configuração original, contribuindo para a não existência das mesmas.

E “apesar de todos os avanços alcançados entre 2008 e 2015 pela gestão ambiental, Paragominas saiu de uma sequência de quedas e voltou a registrar aumento do desmatamento em 2013” (NUNES, 2015, p. 64), informação que por si já causa preocupação diante da possibilidade de retrocesso e retorno a uma configuração nada agradável em se tratando do assunto aqui exposto.

O que transparece algo de favorável é se ter conhecimento de que apesar de uma queda mínima, Paragominas ${ }^{33}$ segue firme nos objetivos a si propostos de não apenas ser considerado como município modelo, mas ser efetivamente um espelho de respeito ecológico e pioneiro em políticas públicas ambientais no Brasil, intimamente envolvido com o reflorestamento de áreas afetadas e iniciativas individuais como os Projetos Vale Florestar ${ }^{34}$, Paragoflor ${ }^{35}$, o Grupo Concrem $^{36}$ e outros contribuindo diretamente para a mudança de direção que Paragominas tem seguido desde que assumiu o compromisso de mudar sua história e posicionar-se contrariamente ao que vinha praticando em décadas passadas.

\footnotetext{
${ }^{33}$ Em notícia publicada no sítio da Prefeitura (https://www.paragominas.pa.gov.br/noticias/meio_ambiente/577-prefeitura_de_paragominas_delimita_areas_de_protecao_permanente_), datando de 24 de janeiro de 2020, informa-se que há um esforço desse órgão administrativo em delimitar as Áreas de Preservação Permanente evitando que sigam sendo objeto de degradação.

34 Esse projeto é gerenciado pelo Fundo de Investimento em Participações Vale Florestar S/A, cuja totalidade das ações foi vendida pela Vale à Suzano Papel e Celulose, em 2014, disponível em: <http://www.vale.com/brasil/pt/aboutvale/ news/paginas/vale-vende-participacao-na-vale-florestar.aspx >. O objetivo do projeto é o de "promover o reflorestamento de áreas degradadas, a recuperação de florestas nativas e remover $\mathrm{CO}_{2}$ atmosféricos através do plantio florestal com a espécie Eucalyptus urograndis com o intuito de fornecer biomassa sustentável para a região propiciando o desenvolvimento socioeconômico local", atundo desde 2007 nos municípios paraenses de "Paragominas, Ulianópolis, Dom Eliseu e Rondon do Pará", disponível em: <https://www.mctic.gov.br/mctic/export/sites/institucional/ciencia/SEPED/clima/mecanismo_de_desenvolvimento_limpo/submetidos/aprovados_termos_resolucao_1/publicacoes/318/ Anexo-III-da-Resolucao-n.-1.pdf>.

35 Esse projeto é iniciativa da reserva florestal Paragominas Reflorestadores Associados, “é uma associação de reflorestadores formada em 2002, inicialmente composta por cerca de 30 produtores madeireiros filiados ao Sindiserpa. A área da associação é de aproximadamente 600 hectares, abrigando cerca de 164 mil árvores plantadas, com predominância de paricá e eucalipto" (PINTO et al., 2009, p. 45).

36 O Grupo Concrem desenvolve atividades no setor madeiro, através de empresas como a Floraplac, a Expama e a Concrem Wood Agroindustrial, informando que atua de maneira sustentável na extração da matéria-prima para seus produtos e em ações de reflorestamento que já somam 31 mil hectares de floresta plantada nos municípios paraenses de "Paragominas, Ipixuna, Ulianópolis, Dom Eliseu e Tomé-Açu”. Disponível em: <https://www.concremwood.com.br/ sobre-nos>.
} 


\section{CONSIDERAÇÕES FINAIS}

De acordo com os elementos expostos no texto que teve por objetivo tratar das Áreas de Preservação Permanentes, pretendendo breves comentários sobre aquelas demarcadas em $\mathrm{Pa}$ ragominas, município situado no nordeste do Pará, a situação dessas áreas no Brasil é merecedora não somente de atenção dos Poderes Constituídos e da sociedade civil como está configurada na categoria de crime ambiental em havendo conduta contrária ao que determina a legislação específica a respeito de seu resguardo e conservação.

As discrepâncias encontradas entre legislações que tratam do assunto - cite-se o Código Florestal, as Resoluções do Conama e afins - deixam claro que a fiscalização, a operacionalização e a aplicação destas bem como a discordância sobre como proceder em determinados casos geram problemas de ordem jurídica, o que finda por abrir espaço para ocupações, desmatamento e uso de seus recursos de maneira inadequada, pois ainda que a legislação brasileira, em comparação com países da Europa e América do Norte, seja mais rígida na letra da lei, há falha perceptível na aplicação desta quando se observa a significativa redução de áreas que deveriam ser objeto de monitoramento, conservação e recuperação beneficiando de maneira ilícita o agronegócio.

De um modo geral, nota-se que em decorrência dos vários aspectos citados a respeito de como as Áreas de Preservação Permanente no Brasil são tratadas tanto nas legislações específicas quanto pelo Poder Público competente e a sociedade civil, tem-se um panorama delicado que as compromete e ameaça sua existência.

Diante desse fato, é necessário que o caso em questão se torne objeto de atenção mais frequente, pois, apesar da experiência positiva e inovadora de Paragominas, em nível nacional muito há ainda a ser feito para que sejam corrigidos desvios legais, institucionais ou situacionais cometidos há décadas, se se tomar como parâmetro de avaliação a primeira legislação que toca no tema, isto é, a Lei n. 4.771/1965 e suas correspondentes atualizações até se alcançar a 12.651/2012 que, apesar de aparentemente representar avanço em muitos aspectos, tem sido alvo de críticas por parte de ambientalistas e órgãos de defesa do meio ambiente, dando a entender que foi publicada mais para atender a interesses dos setores vinculados à Bancada Ruralista no Congresso Nacional que para rever problemas e equívocos persistentes quando o assunto é o meio ambiente no Brasil.

Paragominas expressa em sua trajetória potencial que se sobressai acima das dificuldades costumeiramente apontadas, devendo-se dar atenção às iniciativas e práticas ali desenvolvidas e como nacionalmente poderiam contribuir para o avanço de um cenário que se torne cada vez mais possível: de um país no qual aquilo que há de natural seja tratado por quem se dedica a legislar e por quem pretende fazer uso de tais recursos de maneira mais comprometida, pois a visão de inesgotabilidade dos recursos da natureza já se encontra superada por uma bem mais realista: se não forem dadas condições de manutenção, preservação, conservação e recomposição desses recursos os impactos serão sentidos por toda a população desses territórios como a do município paraense, a curto prazo, e, certamente, de todo o território nacional a médio e longo prazo.

Como se buscou demonstrar, o caminho para a reversão desse delicado quadro passa inevitavelmente pela tomada de consciência da sociedade civil a respeito do problema existente e pelo efetivo cumprimento da legislação, condutas que devem estar acima de vontades e ganhos individuais, pois estes é que findam por estimular práticas predatórias e a continuidade de 
atividades econômicas ilegais de exploração do meio ambiente e responsáveis pelos severos danos causados aos diversos biomas do país.

\section{REFERÊNCIAS}

ACCIOLY, Inny; SÁNCHEZ, Celso. Antiecologismo no Congresso Nacional: o meio ambiente representado na Câmara dos Deputados e no Senado Federal. Desenvolvimento e Meio Ambiente, n. 25, p. 97-108, jan./jun. 2012. Editora UFPR.

ARAÚJO, Suely Mara Vaz Guimarães de. As Áreas de Preservação Permanente e a questão urbana. Câmara dos Deputados. Consultoria Legislativa. Brasília, DF, agosto, 2002. Disponível em: <http://bd.camara.gov.br/bd/handle/bdcamara/1083>. Acessado em: 15 jan. 2020.

BARROS, Ciro; BARCELOS, Iuri. As falhas e inconsistências do Cadastro Ambiental Rural: levantamento da Pública revela que mais de dois terços dos imóveis rurais declarados no CAR do Pará apresentam alguma sobreposição e pelo menos 20 registros definitivos em terras indígenas, o que é proibido. Pública - Agência de Jornalismo Investigativo. Notícia on-line, 1 de agosto de 2016. Disponível em: <https://apublica.org/2016/08/as-falhas-e-inconsistenciasdo-cadastro-ambiental-rural/>. Acessado em: 20 jan. 2020.

BORGES, Luís Antônio Coimbra et. al. Áreas de preservação permanente na legislação ambiental brasileira. Ciência Rural, Santa Maria, v. 41, n. 7, p. 1202-1210, jul., 2011.

BRASIL. Código de Águas e legislação correlata. Brasília, DF: Senado Federal, Subsecretaria de Edições Técnicas, 2003.

Código Florestal e normas correlatas. - Brasília: Senado Federal, Subsecretaria de Edições Técnicas, 2004.

Constituição da República Federativa do Brasil. Brasília, DF: Supremo Tribunal Federal, Secretaria de Documentação, 2019.

Decreto Federal n. 23.793, de 23 de janeiro de 1934. Rio de Janeiro, RJ. Disponível em: <https://www2.camara.leg.br/legin/fed/decret/1930-1939/decreto-23793-23-janeiro-1934-498279-publicacaooriginal-78167-pe.html>. Acesso em: 12 fev. 2020.

COSTA, Leonardo Tropia. Estudo em direito comparado de políticas florestais para as áreas de preservação permanente. Dissertação (Mestrado em Ciência Florestal) - Universidade Federal de Viçosa, MG: UFV, 2008.

EM DISCUSSÃO! - Revista de Audiências Públicas do Senado Federal, v. 2, n. 9, dez. 2011, p. 11. Disponível em: <https://www2.senado.leg.br/bdsf/handle/id/231010>. Acessado em: 15 jan. 2020.

HERZOG, Ana Luiza. Paragominas, a cidade mais invejada da Amazônia: Paragominas, no Pará, já foi chamada de "Paragobalas" - uma cidade marcada pela violência e pelo desmatamento. Hoje serve de inspiração para outros municípios que querem ser verdes. Revista Exame, 12h48, 17 de agosto de 2011. Disponível em: < https:/ / exame.abril.com.br/revista-exame/paragominas-a-mais-invejada-da-amazonia/>. Acessado em: 20 jan. 2020.

IASI, Vico. Projeto combina pecuária modema e preservação da Floresta Amazônica: Pecuária Verde ajuda criadores a recuperarem as matas nativas. Projeto também aumenta a produtividade dos rebanhos. Globo Rural, 09 de novembro de 2014. Disponível em: < http://g1.globo.com/natu$\mathrm{reza} /$ noticia/2014/11/projeto-combina-pecuaria-moderna-e-preservacao-da-floresta-amazonica.html>. Acessado em: 20 jan. 2020. 
IBGE. Paragominas. Disponível em: <https://cidades.ibge.gov.br/brasil/pa/paragominas/historico $>$. Acessado em: 18 jan. 2020.

LEHFELD, Lucas de Souza; CARVALHO, Nathan Castelo Branco de; BALBIM, Leonardo Isper Nassif. Código florestal comentado e anotado (artigo por artigo). Rio de Janeiro: Forense; São Paulo: Método, 2013.

MARTINS, Heron Davi et al. Mapeamento da cobertura do solo de Paragominas-PA com imagens de satélite de alta resolução: aplicações para o Cadastro Ambiental Rural (CAR). Anais XVI Simpósio Brasileiro de Sensoriamento Remoto - SBSR, Foz do Iguaçu, PR, Brasil, 13 a 18 de abril de 2013, INPE, p. 1283-1290. Disponível em: <https://imazon.org.br/PDFimazon/Portugues/congressos\%20e\%20anais/p0598.pdf>. Acessado em: 02 fev. 2020.

MATTOS, Ana Dantas Mendez. Valoração ambiental de áreas de preservação permanente da microbacia do Ribeirão São Bartolomeu no Município de Viçosa, MG. Dissertação (Mestrado em Ciência Florestal) - Universidade Federal de Viçosa, MG: UFV, 2006. MINISTÉRIO DO MEIO AMBIENTE. Cadastro ambiental rural. Disponível em: <https://www.mma.gov.br/informma/item/8243-cadastro-ambiental-rural.html>. Acesso em: 03 fev. 2020.

MOREIRA DA SILVA, Ana Paula; ALVES, Fábio; SAMBUICHI, Regina Helena Rosa; LUEDEMANN, Gustavo. Código Florestal: implicações do PL 1876/99 nas áreas de reserva legal. IPEA. 2011. Disponível em: <http://repositorio.ipea.gov.br/handle/11058/4637>. Acessado em: 15 jan. 2020.

NEIVA, Sigrid de Aquino. As áreas de preservação permanente no Brasil: a percepção de especialistas. Dissertação (Mestrado em Ciência Florestal) - Universidade Federal de Viçosa UFV, MG, 2009.

NUNES, Adriana. O novo Código Florestal brasileiro e a gestão pública municipal na Amazônia: o caso de Paragominas - PA. Dissertação (Mestrado em Gestão dos Recursos Naturais e Desenvolvimento Local na Amazônia) - Universidade Federal do Pará - UFPA, PA, 2015.

PEREIRA, Lucimar Costa et al. Recursos hídricos: estudo das formas de ocupação das Apps de partes do Rio Uraim Paragominas-PA. XIV ENEEAmb, II Fórum Latino e I SBE A - CentroOeste, p. 1005-1013, 2016. Disponível em: <https://conferencias.unb.br/index.php/ENEEAmb/ENEEAmb2016/paper/viewFile/4900/1176>. Acessado em: 23 jan. 2020.

PINTO, Andréia et al. Diagnóstico Socioeconômico e Florestal do Município de Paragominas. Relatório Técnico. Belém/PA: Instituto do Homem e Meio Ambiente da Amazônia - Imazon, 2009. Disponível em: <https://imazon.org.br/PDFimazon/Portugues/outros/ iagnostico-socioeconomico-e-florestal-do.pdf $>$. Acessado em: 23 jan. 2020.

PMP - PREFEITURA MUNICIPAL DE PARAGOMINAS. Lei n. 644/2007, de 23 de maio de 2007. Disponível em: <https://camaraparagominas.pa.gov.br/wp-content/uploads/2019/11/LEI-N\%C2\%BA-644.07-INSTITUI-A-POL\%C3\%8DTICA-MUNICIPALDO-MEIO-AMBIENTE.pdf>. Acessado em: 20 jan. 2020.

Portal do município. Disponível em: <http://www.paragominas.pa.gov.br/>. Acessado em: 20 jan. 2020.

RIBEIRO, Glaucus Vinicius Biasetto. A origem histórica do conceito de Área de Preservação Permanente. Revista Thema, 08 (01), p. 1-13, 2011. Disponível em: < http://www.terrabrasilis.org.br/ecotecadigital/pdf/origem-historica-do-conceito-de-area-de-preservacao-permanente-no-brasil.pdf>. Acessado em: 20 jan. 2020. 
SBPC - SOCIEDADE BRASILEIRA PARA O PROGRESSO DA CIÊNCIA. O Código Florestal e a ciência: contribuições para o diálogo. São Paulo: SBPC, 2011.

SILVA, Laryssa de Cássia Tork da et al. Mapeamento do uso e cobertura da terra em áreas desflorestadas no munícipio de Paragominas - PA nos anos de 1991 e 2008. Anais XV do Simpósio Brasileiro de Sensoriamento Remoto - SBSR, Curitiba, PR, Brasil, 30 de abril a 05 de maio de 2011, INPE. p. 6658-6665. Disponível em: <http://marte.sid.inpe.br/col/dpi.inpe.br/ marte/2011/07.12.12.09/doc/p1206.pdf>. Acessado em: 07 maio 2020.

SIMIONATTO, Ivete; COSTA, Carolina Rodrigues. Como os dominantes dominam: o caso da bancada ruralista. Temporalis, Brasília (DF), ano 12, n. 24, p. 215-237, jul./dez. 2012.

VIANA, Éder Cristiano. Análise jurídico-dogmática da legislação florestal e do direito ao ambiente frente à função social da propriedade. Dissertação (Mestrado em Ciência Florestal) - Universidade Federal de Viçosa - UFV, MG, 2004. 